\title{
Wittgenstein on the Grounds of Religious Faith : A Kantian Proposal
}

\section{Appelqvist, Hanne Kristiina}

2018-09

Appelqvist , H K 2018 , ' Wittgenstein on the Grounds of Religious Faith : A Kantian Proposal

' , European Journal of Philosophy , vol. 26 , no. 3 , pp. 1026-1040 . https://doi.org/10.1111/ejop.12324

http://hdl.handle.net/10138/322001

https://doi.org/10.1111/ejop.12324

acceptedVersion

Downloaded from Helda, University of Helsinki institutional repository.

This is an electronic reprint of the original article.

This reprint may differ from the original in pagination and typographic detail.

Please cite the original version. 
This is the peer reviewed version of "Wittgenstein on the grounds of religious faith: A Kantian proposal" which has been published in final form at http://rdcu.be/Jm4R (DOI:

10.1111/ejop.12324). This article may be used for non-commercial purposes in accordance with Wiley Terms and Conditions for Use of Self-Archived Versions.

\section{Wittgenstein on the grounds of religious faith: A Kantian proposal \\ Hanne Appelqvist}

\section{Religion in Wittgenstein's early thought}

In his early work, Tractatus Logico-Philosophicus, Ludwig Wittgenstein writes:

'Not only is there no guarantee of the temporal immortality of the human soul, that is to say of its eternal survival after death; but, in any case, this assumption completely fails to accomplish the purpose for which it has always been intended. Or is some riddle solved by my surviving for ever? Is not this eternal life itself as much of a riddle as our present life? The solution of the riddle of life in space and time lies outside space and time.

(It is certainly not the solution of any problems of natural science that is required.)' (TLP 6.4312.)

This quote brings to fore three features that together characterize Wittgenstein's early philosophy of religion. These are, first, Wittgenstein's critical stance on methodological naturalism, namely, the view that philosophy is on a par with natural sciences and deals with problems similar to those treated by empirical investigation. Second, Wittgenstein's view that religion is related to and arises as a response to what he calls the riddle or problem of life. This is the problem of seeing one's life as meaningful, valuable, or purposive in the face of its apparent lack of any objective value or purpose. Third, the quote evokes the idea of the transcendentality of space and time, familiar from 
Kant's transcendental philosophy. For Kant, space and time are not properties of the world understood independently of our way of encountering that world, but like the a priori concepts of understanding depend on the transcendental subject to whom that world is given. In accordance with Kant's view, the early Wittgenstein treats space and time as features of the empirically given reality that are however, transcended in experiences of value.

I will start by discussing each aspect of Wittgenstein's early view in light of the Kantian interpretation of his philosophy. ${ }^{1}$ I will argue that Wittgenstein's way of bringing together ethics, aesthetics, and religion under the label 'mystical' echoes Kant's mature strategy of dealing with the grounds of religious faith, presented in his Critique of the Power of Judgment. The overall goal of this paper is to argue that, in spite of the many changes that occur in Wittgenstein developing thought from the 1930s onward, his stance towards religion retains these three aspects that may be read as echoing the Kantian undertones of his early thought.

\section{1. 'The right sort of approach' in philosophy}

In the early 1930s, Wittgenstein describes Kant's method as 'the right sort of approach' in philosophy (LWL: 73). Moreover, at the same time, he connects what he calls the Kantian solution of the problem of philosophy to the idea of a limit of language (CV: 13). For Kant, philosophy is an enterprise qualitatively different from that of the natural sciences. Instead of producing new information about empirical facts, the goal of his critical philosophy is to determine the limits and legitimate application of different types of judgments, namely, cognitive, moral, and reflective judgments. Kant famously describes his project as an attempt to answer three questions that together are meant to give an account of what a human being is. These questions pertain to what I can know, what I should do, and what I may hope (CPR A805/B 833). 
In the Critique of Pure Reason, Kant attempts to answer the first of these questions. He argues that the possibility of theoretical knowledge about the facts of nature rests on the $a$ priori categories of understanding. We can have knowledge of the facts of the world, because the form of our own understanding has an a priori relation to the form of the world (CPR A57/B81-82). In cognitive judgments, sensible content is subsumed under concepts of understanding, thereby yielding empirical knowledge (CPR A51). However, in Kant's account, the realm of theoretical knowledge thus understood excludes notions that pertain, for example, to freedom, God, and eternity. Indeed, as he states in the Preface to his First Critique, he found it necessary to limit the sphere of knowledge to make room for faith (CPR Bxxx). But this just means that, for Kant, the realm of theoretical knowledge leaves untouched equally valid questions that we, as practical agents and as sensible creatures capable of judgments of purposiveness, inevitably encounter in our lives. Hence, in Kant's critical philosophy the question of knowledge is complemented with the two other questions to be treated by his practical philosophy, aesthetics, and teleology.

As argued originally by Erik Stenius, the project of Wittgenstein's early Tractatus is relevantly similar to Kant's project thus described (Stenius, 1960: ch.11). For Kant, the transcendental categories of understanding are constitutive of both empirical facts and cognitive judgments made of those facts. In this sense, the categories limit the legitimate application of cognitive judgments (CPR A57, B81-81). In a similar vein, Wittgenstein limits meaningful language to the realm of facts and treats logical form as a condition of both (TLP 2.18, 3.032, 4.1, 5.61). According to the Tractatus, every meaningful proposition is a picture of a state of affairs. This means that, for a proposition to be meaningful, it must conform to the general propositional form 'This is how things stand' (TLP 4.5). What makes such picturing possible is the logical form shared by the proposition and the state of affairs pictured by it (TLP 2.17). Accordingly, meaningful language is limited to the picturing of facts. Hence, Wittgenstein writes: 'the totality of true propositions is the whole of natural science' (TLP 4.11). 
However, for Wittgenstein, philosophy itself 'is not one of the natural sciences' (TLP 4.111). Instead, Wittgenstein states, 'philosophy sets limits to the much disputed sphere of natural science' (TLP 4.113). Logic - that is, the chief interest of philosophy as understood by the early Wittgenstein - is not among the facts expressible by meaningful propositions (TLP 2.172, 4.121). This is because logical form is the necessary condition for anything to be a fact in the first place or a sentence thereof (TLP 2.18). According to the Kantian interpretation of the Tractatus, this is what Wittgenstein means by stating that 'logic is transcendental' and a priori (TLP 6.13, 5.4731; see CPR A55-57/B79-82). Logical form is the form constitutive of our thought and in this sense a limiting condition of thought (TLP 5.473-5.4733). The main difference between Kant and Wittgenstein arises from Wittgenstein's equation between language and thought. While for Kant, the categories of understanding, as well as such ideas of reason as God that do not correspond to anything in empirical reality, may be thought and expressed, for Wittgenstein, the limits of language are simultaneously the limits of thought (CPR A334-336/B391-394; TLP 3, 3.03). Hence, the domain of meaningful language and thought in the Tractatus parallels Kant's domain of theoretical knowledge, leaving philosophy itself in the position of being an activity rather than a 'body of doctrine' (TLP 4.112). But while Wittgenstein states that the 'correct method of philosophy would really be $[\ldots]$ to say nothing except what can be said, i.e. propositions of natural science', in the Tractatus he himself does not abide by this dictum (TLP 6.53). In fact, he continues the previous statement by adding paradoxically that the propositions of natural science are 'something that has nothing to do with philosophy' (TLP 6.53).

The practice of philosophy is not the only phenomenon that cannot, in Wittgenstein's early view, be captured by means of factual language. Already Stenius points out that, in the Tractatus, there are a number of notions that cannot according to its own dictates be expressed in language. Such ineffabilia mentioned in the Tractatus include ethics and aesthetics, the metaphysical subject, the correct insight of solipsism, the ethical will, God, the sense of the world, the world as a whole, 
as well as the already mentioned logical form (TLP 6.421, 5.632, 5.62, 6.423, 6.432, 6.41, 6.45,

6.13). The attempt to put such ideas into words will inevitably lead to nonsense, i.e., to propositional signs that fail to have factual and as such the only possible semantic content that language can have. Nevertheless, it is important to notice that the list of the Tractarian ineffabilia is in striking parallel with the notions that for Kant remain outside the bounds of theoretical cognition and figure in his treatment of religious faith. (Stenius, 1960: 222-224; see also Moore, 2013: 251253.)

\subsection{Two perspectives on the world}

According to the Tractatus, the facts of the world are devoid of value, and the propositions picturing such facts are all 'of equal value' (TLP 6.4). Hence, Wittgenstein writes that 'propositions can express nothing that is higher' (TLP 6.42). In the Tractatus, Wittgenstein expresses this point also by reference to God: 'How things are in the world is a matter of complete indifference for what is higher. God does not reveal himself in the world' (TLP 6.432). Given that natural sciences are in the business of cataloguing contingent facts, Wittgenstein claims that 'We feel that even when all possible scientific questions have been answered, the problems of life remain completely untouched' (TLP 6.52). This view echoes Kant's position that we cannot have empirical knowledge

of matters related to ethics or religion. Moreover, Wittgenstein's motivation to treat ethics as ineffable reflects Kant's move to limit knowledge to make room for faith. In his letter to Ludwig von Ficker, Wittgenstein famously writes: 'For the Ethical is delimited from within, as it were, by my book; and I'm confident that strictly speaking, it can ONLY be delimited in this way' (Luckhardt, 1979: 94-95). The view underlying this move arises out of a conception of the contingency of the facts of the world on the one hand and the absoluteness of ethics on the other. What can be expressed by means of propositions is just contingent facts that cannot, precisely 
because they are contingent, have the kind of normative force Wittgenstein seems to assign to ethics. As Wittgenstein states in his 1929 'Lecture on Ethics': 'No state of affairs has, in itself, [...] the coersive power of an absolute judge' (E: 7).

However, while denying that value may be found among the facts of the world, Wittgenstein does not deny the possibility of an experience of value, only its reducibility to the facts of the world. He writes: 'The world of the happy man is a different one from that of the unhappy man' (TLP 6.43). The difference between the two worlds is not a difference in facts, for the good or bad exercise of the will cannot alter the facts. And yet, the effect of the exercise of the will is that the world whose facts remain the same becomes 'an altogether different world' (TLP 6.43). Moreover, in the Tractatus, ethics - the relevant viewpoint on the problem of life - is characterized as transcendental and ineffable, just like logic. We read: 'It is clear that ethics cannot be put into words. Ethics is transcendental. (Ethics and aesthetics are one and the same.)' (TLP 6.421.) In the Notebooks, Wittgenstein connects ethics and logic by writing that '[e]thics must be a condition of the world, like logic' (NB: 77).

I have argued elsewhere that Wittgenstein's use of the term transcendental in relation to ethics-cum-aesthetics ought to be understood in the same sense as the transcendentality of the Tractarian logic (Appelqvist, 2013 and 2016). Like logic, which does not handle the empirical content of facts but only their necessary form, ethics does not treat of the facts of the world, for they all reside on an evaluatively neutral level (TLP 6.1-6.12, 6.4-6.42). Instead, the essence of ethics is a form of a feeling. Wittgenstein writes: 'To view the world sub specie aeterni is to view it as a whole - a limited whole. Feeling the world as a limited whole - it is this that is mystical' (TLP 6.45). That Wittgenstein calls the mystical a feeling rather than a thought is not incidental. In the Tractatus, the term 'thought' indicates a proposition with factual content, which cannot have any value (TLP 3, 3.5). It is equally important to notice that the feeling in question is not a mere psychological state. As Wittgenstein notes, 'the will as a phenomenon is of interest only to 
psychology', which in turn deals with contingent facts. Rather, the mystical is a form of a feeling. Accordingly, the sub specie aeterni perspective may be adopted, not just towards the world, but towards any given empirical thing. This is evident from Wittgenstein's remark from 1916:

'As a thing among things, each thing is equally insignificant; as a world each one equally significant.

If I have been contemplating the stove, and then am told: but now all you know is the stove, my result does indeed seem trivial. For this represents the matter as if I had studied the stove as one among the many things in the world. But if I was contemplating the stove it was my world, and everything else colourless by contrast with it.' (NB: 83.)

The point is that as a fact any given thing, like a stove, is devoid of value. But it is possible to adopt a contemplative attitude towards the very same thing that shows it 'as a limited whole' or 'as a world'. While the fact itself remains the same, the sub specie aeterni perspective renders the fact meaningful or significant by relating it to my feeling. It renders the individual fact 'my world' instead of locating the fact in the world as the totality of all the facts (see TLP 1.11-1.12).

The idea of seeing a trivial thing as meaningful brings us to the second aspect of Wittgenstein's treatment of religion, namely, to the problem of life. This is the problem of seeing one's life as meaningful or purposive despite the fact that understood as a collection of facts it has no meaning or purpose. In 1916, Wittgenstein writes:

What do I know about God and the purpose of life?

I know that this world exists.

That I am placed in it like an eye in its visual field.

That something about it is problematic, which we call its sense.

That this sense does not lie in it but outside it.

That life is the world.

That my will penetrates the world. 
That my will is good or evil.

Therefore that good and evil are somehow connected with the sense of the world. (NB: $72-$ $\left.73 .{ }^{2}\right)$

Given his characterization of ethics as transcendental, it would be natural to assume that Wittgenstein would look for an answer to the problem of life in the realm of ethics understood as an investigation into what one should do or how one ought to act. For Kant, it is primarily our practical knowledge of ourselves as agents bound by an apodictically commanding moral law that gives rise to the postulates of practical reason. Kant's point is, roughly, that the absoluteness of the moral demand forces me to think of myself as free. Moreover, the dramatic contrast between the absolute moral command on the one hand and the imperfections and injustice of the empirical reality on the other gives us grounds to think, if not have knowledge, of the soul as immortal and of God as existing. In short, my experience of myself as a moral being gives me a practical justification to hope for the realization of the highest good, i.e., the moral development of the subject and the ultimately just distribution of happiness based on moral worth. While there is no objective necessity, i.e. duty, to assume that the soul is eternal and that God exists, there is a subjective necessity, i.e. a need, arising from the absolute command of the moral law to think that this is the case (CPrR 5:125; see CPrR 5:122-132).

However, by contrast to Kant, whose categorical imperative not only commands respect but also determines what empirical acts are in conformity with the moral law, the early Wittgenstein turns away from the view of ethics as essentially connected with the specific content of actions to be tested against an explicit principle such as the categorical imperative (see G 4:400). He writes: 'When an ethical law of the form, 'Thou shalt...', is laid down, one's first thought is, 'And what if I do not do it?' It is clear, however, that ethics has nothing to do with punishment and reward in the usual sense of the terms. So our question about the consequences of an action must be unimportant.' (TLP 6.422.) 
Here, Wittgenstein joins Kant in rejecting the consequences of an action as irrelevant for its moral value (G 4:394). But by contrast to Kant, he denies that any ethical law could have the kind of apodictic force that Kant attributes to the moral law that is supposed to command actions unconditionally purely based on its form (G 4:414-415). In fact, Wittgenstein takes the view further by suggesting that any act understood as an empirical fact and even any attitude understood as a psychological state, is as contingent and value-neutral as any other fact of the world. Even murder, he claims, taken as a fact, is 'exactly at the same level with any other event' (E: 6). And as if this were not enough, Wittgenstein claims that the world is independent of my will: 'Even if everything that we want were to happen, this would still only be, so to speak, a grace of fate' (NB: 73; see TLP 6.373). ${ }^{3}$ Hence, while he makes a distinction between good and bad willing - and in so doing follows Kant rather than Schopenhauer, who is often mentioned as the source of the Kantian features of Wittgenstein's early thought ${ }^{4}$ - Wittgenstein denies the connection between my willing and the facts of the world. He writes: 'If good and evil willing affects the world it can only affect the boundaries of the world, not the facts, not what can be expressed by means of language' (TLP 6.43). These two commitments, namely, the denial of the value of any facts and the independence of the world of my will, effectively block the route to an understanding of Wittgenstein's early ethics as answering Kant's practical question of what I should do. Accordingly, they also undermine the possibility of treating eternity and God in a fashion similar to Kant's postulates of practical reason.

Nevertheless, I would like to argue that Wittgenstein's solution to the problem of life still draws on Kant's philosophy. However, it does this by evoking a train of thought familiar from Kant's mature treatment of the question of what I may hope. In the Critique of the Power of Judgment, Kant addresses the question of hope in terms that differ from his treatment of the topic as part of moral philosophy. Here, in the Third Critique, Kant distinguishes between two mutually exclusive but equally important perspectives on nature, arguing that the distinction will help in building a bridge between the deterministic domain of nature and the domain of freedom (CPJ 
5:171-179). The first perspective on nature stems from cognitive judgments that Kant now calls determining, given that they subsume particulars under conceptual rules and thereby yield objectively valid empirical cognition. This determining perspective shows nature and its organisms as 'mere aggregates' of facts, as something mechanical (CPJ 20:217). But now Kant argues that there is another perspective on nature, which arises from the reflective use of the power of judgment and shows the very same organisms and eventually the entire nature as unified organized systems (CPJ 5:373). While we may look at a natural organism, like a tree, from the determining perspective of discursive reasoning and explain the tree by subsuming it under conceptual principles (e.g. by explaining how it falls under certain mechanistic laws of nature), we may also see the organism as purposive, see, for example, the green of the leaves as if intended for a certain function within the system of the tree. Indeed, according to Kant we cannot help but look at the tree also in this way (CPJ 5:360, 365).

Moreover, Kant claims that in approaching nature from the reflective perspective as purposive and unified, we are 'strictly speaking, relieved of a need' (CPJ 5:184). This need is not unconnected from the need (i.e. subjective necessity) that Kant brings up in his discussion of the postulate of God's existence (CPrR 5:125). For both discussions point to the 'transcendental concept of reason of the supersensible', even if the grounds for assuming such a concept differ in the case reflective judgment from the grounds that our experience of moral obligation gives (CPJ 5:339). Kant argues that when perceived as a unified purposive whole, nature may be compared to art or to life itself (CPJ 5:374; cf. TLP 5.621). The reflective judgment shows the organism and its parts as if they were intended for a certain purpose even when it may turn out to be impossible to explain what that purpose is (CPJ 5:220). Hence, the reflective perspective evokes the idea of a will (of a creator) that has designed the world in accordance with a particular purpose, even if the determining use of the power of judgments does not warrant the attribution of such purposes to nature (CPJ 5:398). In Kant's view, this means that reflective judgments do not warrant scientific 
explanations but only elucidations or descriptions (CPJ 5:412, 417). ${ }^{5}$ This is because they rest upon a principle that the power of judgment gives to itself in its reflective use without having a legitimate domain of application outside its own reflective use. Kant writes:

'Objectively, therefore, we cannot establish the proposition that there is an intelligent original being; we can establish it only subjectively for the use of our power of judgment in its reflection upon the ends of nature, which cannot be conceived in accordance with any other principle than that of an intentional causality of a highest cause' (CPJ 5:399).

Nevertheless, while we cannot know that the world is purposive, the reflective judgment itself suffices to strengthen our hope in an intentionality underlying the world.

Interestingly enough, Kant claims that we are familiar with the grounds of such hope, namely, with the principle of formal purposiveness, from a judgment of beauty. This is because a judgment of beauty is merely reflective, as it rests on the judging subject's feeling in the contemplation of an object as a purposive whole for which no conceptually determinable purpose may be identified (CPJ 5:194). By contrast to teleological judgments about the purposiveness of nature that give rise to concepts, the judgment of beauty is neither based on concepts, nor leads to any concepts. Instead, it rests on my personal feeling of pleasure in the face of a representation I judge to be beautiful. But in spite of its ground in a feeling Kant argues that the judgment of beauty makes a claim to necessity. I claim that the feeling of pleasure I feel is one that you ought to feel as well, even if I cannot force you to accept my judgment by appealing to conceptual justifications (CPJ 5:237). ${ }^{6}$ Indeed, the entire argument of the Third Critique is intended to show that a subjectively based judgment may be treated as universally valid and making a rightful claim to necessity.

I would like to suggest that these two perspectives introduced in Kant's Third Critiquethe determining perspective of cognitive judgments and the reflective perspective on the purposiveness of nature - are echoed in Wittgenstein's early philosophy. The determining 
perspective of cognitive judgments corresponds to the Tractarian world as the totality of contingent and mutually independent facts, describable by meaningful language and yielding empirical science as the 'totality of true propositions' (TLP 4.11). When for Kant, the conditions for theoretical cognition are the transcendental categories of understanding, for Wittgenstein the world of facts is conditioned and limited by the transcendental logical form (TLP 1.1, 2.061, 4.26, 5.134). Moreover, in accordance with Kant, Wittgenstein denies that the perspective employed by the natural sciences can address the question of the purposiveness we may nonetheless experience in the world purposiveness that Wittgenstein describes as the mystical 'feeling of the world as a limited whole' (TLP 6.45). ${ }^{7}$ And yet, it is precisely this question of the 'sense of the world' that Wittgenstein mentions as one of his unquestionable starting points (NB: 73). In the Tractatus, then, the perspective resulting from the application of transcendental logic is complemented by the equally transcendental perspective of ethics-cum-aesthetics. Ethics-cum-aesthetics occupies a perspective that shows one's life from the viewpoint of eternity in the same sense as we may approach a work of art as a meaningful and purposive whole even when we cannot say what it is that makes it meaningful (see NB: 40; cf. BB: 166-167; PI $\S 527,531$ ). This is to say that, in accordance with Kant who treats the judgment of beauty as the paradigm example of a reflective judgment, Wittgenstein takes the essence of all valuation, whether ethical or aesthetic, to reside in the reflective perspective: 'The work of art is the object seen sub specie aeternitatis; and the good life is the world seen sub specie aeternitatis. This is the connexion between art and ethics.' (NB: 83.)

\subsection{The view from eternity}

The reflective perspective brings to the fore the transcendentality of space and time in Wittgenstein's early thought. Up to now, I have treated the transcendentality of logic and of ethics in terms of a form - whether logical or reflective - that is necessary for the possibility of factual 
propositions or value judgments respectively. But in the remark quoted at the very beginning of this paper, Wittgenstein claims that 'The solution of the riddle of life in space and time lies outside outside space and time' (TLP 6.4312). This suggests that Wittgenstein takes space and time to be constitutive of the factual viewpoint. And indeed, in the Tractatus, space and time are mentioned as forms of objects that are the unalterable and subsistent constituents of facts (TLP 2.021, 2.023, $2.0251) .^{8}$

However, as I have argued, this factual viewpoint may be set aside while engaged in the contemplation of an object or the world as a limited whole. ${ }^{9}$ The resulting change in the perspective on the world is manifest in my experience of the spatio-temporality of the world as well. In his 1916 notes, Wittgenstein writes: 'The usual way of looking at things sees objects as it were from the midst of them, the view sub specie aeternitatis from outside. In such a way that they have the whole world as background. Is this it perhaps - in this view the object is seen together with space and time instead of in space and time?' (NB: 83). To view the world sub specie aeterni is to view it from the viewpoint of eternity. But it does not follow that we need to understand eternity as an infinite duration of time. Rather, the reflective perspective on life as a purposive whole means overcoming the factual perspective and temporality itself as a formal feature of experience. Wittgenstein writes, 'if we take eternity to mean not infinite temporal duration but timelessness, then eternal life belongs to those who live in the present' (TLP 6.4311). It belongs to those who pause to contemplate life itself as a limited whole.

For Kant, the judgment of beauty as a merely reflective (nonconceptual) judgment differs from moral judgments by being disinterested. While a moral judgment is not based on the consequences of an action, it nevertheless gives rise to an interest in the realization of the highest good. In a judgment of beauty, however, all interest in the existence of its object is set aside, and the feeling of pleasure arises from a disinterested and free contemplation of the purposive form of the representation of the object. As explained above, Wittgenstein has blocked the availability of any 
interest in ethics by claiming that the facts of the world are devoid of value and independent of my will. Not surprisingly, then, his descriptions of the sub specie aeterni viewpoint stress its disinterested character. Wittgenstein writes: 'Whoever lives in the present lives without fear and hope' (NB: 76). And again, 'The only life that is happy is the life that can renounce the amenities of the world' (NB: 81).

We have seen that no facts delivered by the empirical sciences can succeed in answering the problem of life, because the problem of life is not a factual problem to begin with. And by proposing temporal immortality as an answer to the ethical problem of seeing one's life as meaningful it assimilates - mistakenly in Wittgenstein's view - the ethically relevant perspective on one's life with the spatio-temporal, empirical conception on life. Rather, the solution to the problem of life lies in my ability to see the empirical reality in such a way that it ceases to be problematic, from a timeless perspective. And it is this insight of the irreducibility of value to facts and the availability of the reflective perspective that Wittgenstein attributes to religious faith and indeed treats as its core:

'To believe in a God means to understand the question about the sense of life.

To believe in a God means to see that the facts of the world are not the end of the matter.

To believe in God means to see that life has sense.' (NB: $74 .{ }^{10}$ )

Hence, by contrast to the traditional understanding of 'seeing that the facts of the world are not the end of the matter', cashed out in terms of an idea of the Last Judgment occurring in temporally understood eternity, Wittgenstein locates the core of religious faith in the very rejection of the factual perspective on the world as the only available perspective. In this respect, i.e., by locating the ground of religious faith in an experience of the purposiveness of one's life rather than knowledge, Wittgenstein may still be read as following in Kant's footsteps.

\section{The later Wittgenstein on religious faith}




\section{1. 'Our inquiry is therefore a grammatical one' (PI $\S 90)$.}

When Wittgenstein returns to philosophy in the 1930s, he quickly assumes a critical stance towards his earlier account of language. The main target of his criticism is the idea that every meaningful sentence must conform to the general propositional form 'This is how things stand', grounded in the forms of unalterable objects (M 5:30, 7:39, 7:88, 7:92; PI $\S 65,114,134-136)$. According to his later view, there are multiple ways of using language each constituted by their own respective sets of grammatical rules (PI $\S \S 23,108)$. But in spite of this important difference, there is also an important point of continuity in Wittgenstein thought, pertaining to his rejection of methodological naturalism. This continuity finds expression in Wittgenstein's mature remark in the Philosophical Investigations:

'It was correct to say that our considerations must not be scientific ones. The feeling "that it is possible, contrary to our preconceived ideas, to think this or that" - whatever that may mean could be of no interest to us. [...] And we may not advance any kind of theory. There must not be anything hypothetical in our considerations. All explanation must disappear, and description alone must take its place. And this description gets its light - that is to say, its purpose - from the philosophical problems. These are, of course, not empirical problems [...]' (PI § 109.)

The contrast drawn here between philosophical description on the one hand and empirical explanation on the other is a recurring theme in Wittgenstein's later work (TLP 3.33, 5.552, 6.111; PI $\S 90,109,251,295,458)$. The proper method of philosophy, recommended by the later Wittgenstein, is to 'leave everything as it is', and to just describe the actual uses of language (PI $\S$ 124). While these uses are, in Wittgenstein's later account, historically and culturally variable and practice-laden, they are nonetheless structured by grammatical rules (PI $\S \S 83,108)$. These rules are 
not regulative rules, but constitutive of the ways in which language is actually used, like the rules of chess without which we could not play the game of chess. The rules are also autonomous in that they cannot be justified by appeal to anything extralinguistic, like empirical facts (PI § 497). Still, grammatical rules are essential for the possibility of linguistic communication. Unless we agree on the rules of grammar, our possibility of agreeing or even disagreeing on matters of empirical fact and opinion quickly dissolves (PI §§ 240-242). Hence, one could argue that even the later Wittgenstein treats the form of language as a condition for the possibility of saying something in the first place and in this sense akin to his early logic.

Part of Wittgenstein's later conception of linguistic communication is the notion of understanding as a normative issue. To use a symbol commits the user to follow the grammatical rules. Part of this commitment is the speaker's ability to justify her application of the rule by giving reasons. However, while there are cases in which I can justify my application of a rule, I will soon out run out of such justifications (PI $§ 217$ ). Interestingly, the point where reason-giving ends still lies, in Wittgenstein's imagery, at the limit of language: 'A reason can only be given within a game. The links of a chain of reasons come to an end, at the boundary of the game' (PG: 97; see PI $\S$ 326, 482, 485). Moreover, Wittgenstein continues to connect the practice of philosophy, now understood as grammatical investigation, to the idea of a limit of language (PI $§ 119$ ). However, while the mature Wittgenstein still treats grammar as that which excludes nonsense, he now emphasizes that such limits are always drawn for a particular purpose: 'To say 'This combination of words has no sense' excludes it from the sphere of language, and thereby bounds the domain of language. But when one draws a boundary, it may be for various kinds of reasons.' (PI § 499.) An important difference between Wittgenstein's early conception of logical form and his later notion of grammar is that while logical form is strictly speaking ineffable, grammatical rules may be formulated. However, grammatical rules are akin to logical form in the sense that they do not have empirical content: they are not used as statements of facts but rather taken for granted 
without justification thus making the justification of ordinary statements possible. Wittgenstein even claims that uttering basic certainties, akin to grammatical sentences in that they form the foundation of our language-games, amounts to nonsense (OC $\S 32-35,401$, 403). (See McGinn, 1999: 502, 512; Moyal-Sharrock, 2007: 157.)

In Wittgenstein's later view, then, the limits of language are reached at the boundary of a language-game, where justifications have been exhausted and we simply take for granted the grammatical rules themselves. At this boundary or bedrock, we can only act or else, for purposes of philosophical clarification, describe the game in question (PI $\S 217,261)$. Moreover, just like in the Tractatus, where the limit of language indicated logic but also ethics, aesthetics and religion, in the 1930s too Wittgenstein places aesthetics, ethics and religion as well as philosophy itself on this boundary of language where empirical justifications come to an end and the only method left available is description.

\section{2. 'The edge of the abyss' (CV:34)}

In the early 1930s Wittgenstein says: 'Philosophy may expect to arrive at fundamental propositions. But great event to which we come is the coming to the boundary of language: there we can't ask anything further' (M 5:28). A particularly poignant example of an end, where the understanding of a sentence cannot be cashed out simply in terms of definitions and rules of grammar upon which all members of the linguistic community agree, surfaces in Wittgenstein's treatment of religious belief. In 1938, he discusses the possibility of an understanding between someone who believes in the Last Judgment and himself, Wittgenstein, as someone who does not. He starts the discussion by envisioning a conversation started by the believer who asks him, 'Wittgenstein, do you believe in this [i.e. in Last judgment]?' Wittgenstein claims he would say no. But what follows shows that the case is anything but straightforward. For Wittgenstein claims that, in explaining his own view, he 
would not say that 'I believe in the opposite'. Nor would he say that 'There is no reason to suppose such a thing.' (LC: 53). According to Wittgenstein, to adopt the second line, namely, that 'there is no reason to suppose such a thing', is to miss the whole point of the religious claim. Quite stunningly, Wittgenstein states that he cannot contradict the religious person:

'In one sense, I understand all he says - the English words "God" etc. I understand. I could say: "I don't believe in this", and this would be true, meaning I haven't got these thoughts or anything that hangs together with them. But not that I could contradict the thing.

You might say: "Well, if you can't contradict him, that means you don't understand him. If you did understand him, then you might.” That again is Greek to me. My normal technique of language leaves me. I don't know whether to say they understand one another or not.' (LC: 55.)

This remark suggests that, in Wittgenstein's view, the disagreement between him and the believer does not depend on a lack of linguistic competence on his part. He may understand the word 'God' 'in one sense', as Wittgenstein says; for example, he may have knowledge about the ways in which God is characterized in the Bible and in the Christian tradition and in this sense master 'theology as grammar' (PI § 373). Yet, something is amiss for the possibility for Wittgenstein to fully comprehend the religious claim, to understand it in a sense relevant for religious faith. His 'normal technique of language leaves' him here, as he says (LC: 55).

To shed light on the difficulty, Wittgenstein draws a contrast between the religious controversy on the Last Judgment with an ordinary empirical disagreement. According to him, if one says 'There's a German aeroplane overhead' and the other says 'Possibly, I'm not sure', the two are relatively close to one another. However, if the believer says 'There is Last Judgment.' and someone responds 'Well, I'm not sure. Possibly.', there is an enormous gulf between the two. By contrast to the empirical case, where we can play the game of assigning probabilities to empirical 
statements without losing much and have a shared understanding of how the statement could (at least in principle) be confirmed, the religious belief in Last Judgment cannot be corroborated with evidence. Not with evidence of the standard empirical variety anyway. Nor do people of faith subject religious statements to the kinds of doubt that they would normally apply or treat religious statements as a matter of reasonability. In this respect, religious people treat religious statements in a manner that resembles the way in which Wittgenstein takes us to treat basic certainties. Indeed, Wittgenstein uses the term 'certainty' in relation to religious faith and points out that it sounds odd to call religious beliefs opinions or knowledge (CV: 38; LC: 57; cf. PI § 241).

Moreover, while Christianity is related to historical events, in Wittgenstein's view it is not based on a historical truth. In his personal notes at the time of the lectures on religious belief, Wittgenstein writes:

'Queer as it sounds: the historical accounts of the Gospels might, in the historical sense, be demonstrably false, \& yet belief would lose nothing trough this: but not because it has to do with "universal truths of reason"! rather, because historical proof (the historical proof-game) is irrelevant to belief. This message (the Gospels) is seized on by a human being believingly (i.e. lovingly): That is the certainty of this "taking-for-true", nothing else.' (CV: 37-38, see also LC: 57.)

Instead of basing itself on historical truth, Christianity 'presents us with a (historical) narrative \& says Now believe!' (CV: 37). But one is not supposed to believe the narrative of Christianity as one would believe a historical report. Instead, the force of the narrative is different. Wittgenstein writes: 'Here you have a message! - don't treat it as you would another historical message! Make a quite different place for it in your life.' (CV: 37). For no fact, no matter how well established or even indubitable, 'would be enough to make me change my whole life' (LC: 57). Hence, when it comes to religious belief 'the best scientific evidence is just nothing' (LC: 56). Rather than knowledge or opinion, the taking-for-true is, in the case of the Gospels, love. It is not that the Gospel is not taken- 
for-true by the believer, but rather that truth in the religious case is not explained by reference to the historical or scientific proof game. ${ }^{11}$ Wittgenstein writes: 'Religion says: Do this! - Think like that! but it cannot justify this and it only need try to do so to become repugnant; since for every reason it gives there is a cogent counter-reason' (CV: 34). Rather, Wittgenstein states, 'Religious similes can be said to move on the edge of the abyss' (CV: 34$)$.

To be sure, there are those who treat religious beliefs on a par with ordinary empirical and everyday beliefs. Religious evidentialists and scientistic atheists alike start from the assumption that religious doctrines may be supported or rejected based on evidence relevantly similar to the

evidence given for empirical statements. They both start by assuming that the standard of rationality we employ in relation to ordinary everyday beliefs and to scientific hypotheses applies straightforwardly to the religious case as well. Wittgenstein knew this too, as he brings up Father O'Hara as an example of a person who makes religion into a question of science. However, Wittgenstein claims that such a move just makes religion into mere superstition. According to him, 'Not only is [religion] not reasonable. It does not pretend to be' (LC: 58). So again, in accordance with his early view, Wittgenstein directs his criticism against the assumption that we could make sense of the wealth of human experience by reducing it to the perspective employed by natural sciences. Rather, just like Kant before him, Wittgenstein is careful to distinguish religious faith from knowledge and opinions by pointing out that the grounds for faith are qualitatively different from the grounds we evoke in the case of knowledge (see CPR A820-827/ B848-855).

\subsection{Reasons in religion?}

It is often claimed that Wittgenstein's rejection of the evidentialist understanding of religious faith reflects his inaccurate view of how religious people sometimes as a matter of fact think. However, as argued by Severin Schroeder, Wittgenstein's description of some aspects of religious faith does 
not fall prey to this all too common criticism. Instead, as Schroeder points out, Wittgenstein seems to be more concerned with outlining the kind of faith he himself found appealing, 'the kind of faith he would have liked to have', faith that acknowledges that 'the arguments from natural theology are unconvincing'. (Schroeder, 2007: 443-445, 459.) ${ }^{12}$ In this respect, Wittgenstein's discussion of religion in the 1930s may be seen as a continuation of a personal search that had begun already during the First World War, when he declared that 'to believe in God means to see that the facts of the world are not the end of the matter' (NB: 74).

Indeed, what still motivates Wittgenstein's rejection of empirical evidence as relevantly grounding religious faith is the assumption we have encountered already in his early treatment of ethics. While the facts of the world are contingent and hence 'a matter of complete indifference for what is higher', the ethical demand as understood by Wittgenstein is absolute. If religious faith were a matter of forming informed opinions based on evidence of the kind that we use in the justification of scientific and everyday statements, then one ought to abandon that faith in light of possible counterevidence. Yet, as John Hyman acutely summarizes it, 'Wittgenstein defends the view that religious beliefs are [...] immune from falsification and from verification' (Hyman, 2001: 7). The role that religious faith plays in the lives of those who endorse it is more fundamental than that. According to Wittgenstein, for a person who has faith, that faith is a matter of 'unshakeable belief' that manifests itself, 'not by reasoning or by appeal to ordinary grounds for belief, but rather by regulating for in all his life' (LC: 54).

The question is, then, whether religious people have any grounds for their faith? What can compel someone to let faith 'regulate for in all his life'? Wittgenstein mentions two examples that are quite extraordinary. The first example is from Kierkegaard, who describes a childhood memory of his father setting him a task. The weight of the duty and his sense of responsibility was so heavy, he claimed, that he realized that not even death could take away the responsibility of fulfilling this task. And this experience of duty was, in a way, a proof of the immortality of the soul. (M 7:79) 
While the view expressed here resembles Kant's postulate of immortality as based on moral duty and thus rests on the contrast between the moral demand and the contingency of nature, it need not lead to a postulate of immortality understood in a temporal sense. Rather, the absoluteness of the moral demand indicates that the empirical perspective on one's life, now understood as the ways in which people as a matter of fact talk, act, and live, does not fully capture the normative force of the ethical demand.

Another example given by Wittgenstein is a dream someone has about the Last Judgment and then makes it instructive for his life. Comparing the case to an obvious miscalculation performed on a blackboard, Wittgenstein says: 'There are cases where I'd say he is mad, or he's making fun.' But interestingly, he continues: 'Then there might be cases where I look for an entirely different interpretation altogether. In order to see what the explanation is I should have to see the sum, to see in what way it is done, what he makes follow from it, what are the different circumstances under which he does it, etc.' (LC: 62). Applied to the religious case, this would mean to look for what role the religious person gives to religious faith in his or her entire life, what kinds of choices the person makes based on it, and how these choices shape the person's life as a whole. While phrased in terminology different from Wittgenstein's early position, the view is not altogether different from that expressed in the Tractatus by reference to the difference between the worlds of the happy and the unhappy man, between one who sees one's life as meaningful and the other who fails to see it as such.

The force of these examples as grounds for religious faith lies in the contextual understanding of the phenomenon. The explanation of a religious belief does not appeal to a principle or fact independent of the belief itself, but rather aims at understanding it by placing it into a system - a mathematical system or a narrative of a life - within which it has a purpose. Hence, Wittgenstein claims: 'If they do something very like one of our blunders, I would say, I don't know. It depends on further surroundings of it' (LC: 59). Moreover, in suggesting that the grounds for religious faith 
arise out of the role the religious beliefs have in the believer's life, Wittgenstein is in fact appealing to a model he evokes in relation to aesthetic judgments. In Wittgenstein's view, aesthetic judgments are treated as normative in the sense that they are not mere subjective responses but make a claim to correctness or even necessity (LC I: 8, 15; M 9:39; CV: 65). However, while the rules of a given aesthetic field (like music) are constitutive for the possibility of the meaning and the understanding of music and may be evoked in aesthetic explanations and serve as standards of correctness, the aesthetic judgment cannot be exhaustively explained by reference to these rules. This is because in addition to being 'drilled in harmony and counterpoint', the possibility of aesthetic judgments also requires that one has 'developed a feeling for the rules' (LC I: 15, 17, II: 10-16; PI § 535).

In Wittgenstein's account, aesthetic explanations are not empirical, but 'grammatical' (LC II: 17-19, III: 7). They aim at showing how the pieces of an 'aesthetic puzzle' 'click into place' in such a way that one is satisfied (LC III: 1, 4). Hence, the kinds of reasons given in aesthetics are of the nature of further descriptions of the aesthetic system that aim at showing why the pieces of the aesthetic puzzle fit together to form a unified whole (M 9:30, 9:33-34, 9:40, 9:47; LC III: 1-5). ${ }^{13}$ Wittgenstein gives the following example: “"Why is this note absolutely necessary?” Explanation would look like this: If you wrote out the tune in chords, you would see to which chord the note belongs. I.e. it hints at placing side by side with the tune a certain chorale.' (M 9:39.) The aesthetic explanations given by comparisons and further descriptions thus aim at showing how the note completes the chord or how a church mode comes to an end (see M 9:41; PI $§ 535$ ). In fact, in the 1930s, Wittgenstein suggests that, in addition to approaching meaning 'discursively' as a calculus that may be taught to another, there is also an 'intuitive' way of approaching meaning. This means 'taking something in as a whole at a glance', 'overlooking a system at a glance' (M 8:59, 9:38). Moreover, while the majority of examples of this latter perspective deal with grammatical systems, Wittgenstein evokes the notion of a system and the possibility of 'overlooking' it in relation to aesthetic judgements as well (M 9:33, 9:40). 
Interestingly, however, Wittgenstein writes: 'We are again and again using this simile of something clicking and fitting, when really there is nothing that clicks or that fits anything' (LC III: 5). One way to understand this remark is to take it as a variation of the Kantian principle of purposiveness without objective purpose, which I suggested is the core of Wittgenstein's early solution to the problem of life, namely, the sub specie aeternitatis perspective shared by ethics and aesthetics. While it is possible to appeal to the rules of an aesthetic system in explaining one's aesthetic judgment - just as the believer may cite the creed or quote the Church Fathers to explain her religious beliefs - or explain one's judgment by comparing it with something else, these explanations do not force another person to accept the judgment. As Wittgenstein writes: 'Above all he did not have to accept the explanation; it is not after all as though I had given him compelling reasons for comparing this passage with this \& that' (CV: 79). And again: 'A solution must speak for itself. If when I've made you see what I see, it doesn't appeal to you, there is an end.' (M 9:31.)

The point seems to be that, while one cannot justify the necessity of the note discursively, say, by appeal to a principle independent of the musical system itself, one may nonetheless feel its necessity when heard in the context of the musical theme as an organized whole (LC I: 15; PI § 535). Similarly, in order to see how faith may indeed 'regulate for all in [one's] life' in spite of lacking an empirical or historical foundation, we have to place it in the context of a life (LC: 54). Wittgenstein writes, 'religious belief could only be (something like) passionately committing oneself to a system of coordinates. Hence, although it's belief, it's really a way of living, or a way of judging life' (CV: 73, emphases added). The way of judging life in question, i.e., the sense of understanding Wittgenstein claims he himself is missing, takes the form of reflective judgment as outlined by Kant and evoked by the early Wittgenstein (cf. LC: 55). This is to say that the grounds for faith arise out of a perspective on one's life as a limited whole, a perspective that the early Wittgenstein described as one that shows life sub specie aeternitatis and identified as the common core of ethics, aesthetics, and religion (NB: 83; TLP $6.45^{14}$ ). 
Consider Wittgenstein personal diary note from 1930:

'Engelmann told me that when he rummages round at home in a drawer full of his own manuscripts, they strike him as so glorious that he thinks they would be worth presenting to other people. But when he imagines a selection of them published he said that the whole business loses its charm \& value \& becomes impossible.'

According to Wittgenstein, the case is as follows:

'When Engelmann looks at his writings and finds them splendid ... he is seeing his life as God's work of art \& and as such it is certainly worth contemplating, as is every life \& everything whatever. But only the artist can represent the individual thing so that it appears to us as a work of art; those manuscripts rightly lose their value if we contemplate them singly \& in any case without prejudice, i.e. without being enthusiastic about them in advance. The work of art compels us - as one might say - to see it in the right perspective, but without art the object is a piece of nature like any other $\&$ the fact that we may exalt it through our enthusiasm does not give anyone the right to display it to us.' (CV: 6-7.)

Here, Wittgenstein is explicitly appealing to the aesthetic perspective as the 'right' perspective on life, which allows us to overcome the facts constituting that life as mere facts. Seen as an aggregate of natural facts, life has no value. However, it is possible to see the very same facts as a worth contemplating, as if their totality were God's work of art, a purposive whole even when we cannot state what that purpose might be.

Recall the contrast I attributed to Wittgenstein's early philosophy between the two ways of approaching the world. The first sees the world as an aggregate of empirical facts describable by natural sciences, the second shows the same world as a limited whole and as such meaningful. I argued that this contrast corresponds to Kant's distinction between determining and reflective judgments. In my reading, the later Wittgenstein still adheres to the distinction, drawing a contrast between empirical, causal explanations and the kinds of explanations given in aesthetics, i.e., 
explanations taking the form of further descriptions or comparisons that only aim at showing a grammatical, mathematical, or aesthetic system as a whole. It is this latter reflective perspective that lies underneath Wittgenstein's remarks on religious belief. If one believes in the Last Judgment based on a narrative with no more than moderate historical plausibility, if one believes based on an experience of an absolute moral duty, or based on a dream, then the reason one has is not of the discursive variety at all. Instead, the reason one has for one's religious conviction arises from the light the narrative, dream, or experience sheds on one's life. Again, the operative notion of life here is not life as understood by empirical sciences. Rather, it is life seen as a complete whole, in other words, life seen from the reflective perspective. This perspective brings together the three features I started by identifying as the core of Wittgenstein early remarks on religion, namely, the rejection of methodological naturalism, the view of religion as arising out of the problem of life, and the possibility of overcoming the empirical perspective as the solution to that problem. ${ }^{15}$

\section{References}

\section{Works cited by abbreviation} Matthews (Tr.). Cambridge: Cambridge University Press.

CPR Kant, I. (1998). Critique of Pure Reason. P. Guyer and A. Wood (Tr. \& Ed.). Cambridge: Cambridge University Press. 
Wittgenstein on the Grounds of Religious Faith

CPrR Kant, I. (1997). Critique of Practical Reason. M. Gregor (Tr. \& Ed.). Cambridge: Cambridge University Press.

G

Kant, I. (1997). Groundwork of the Metaphysics of Morals. M. Gregor (Tr. \& Ed.).

Cambridge: Cambridge University Press.

CV Wittgenstein, L. (1998). Culture and Value. G. H. von Wright \& A. Pichler (Eds.), Peter Winch (Tr.). Oxford: Blackwell.

$\mathrm{E}$ Wittgenstein, L. (1974a). Lecture on ethics. The Philosophical Review, 74:1, 3-12.

LC Wittgenstein, L. (1966). Lectures and Conversations on Aesthetics, Psychology and Religious belief. C. Barrett (Ed.). Berkeley: University of California Press.

LWL Wittgenstein, L. (1979). Wittgenstein's Lectures, Cambridge 1930-32. D. Lee (Ed.). Oxford: Blackwell.

M

Wittgenstein, L. (2016). Wittgenstein: Lectures, Cambridge 1930-1933 from the Notes of G. E. Moore. D. Stern, B. Rogers, and G. Citron (Eds.). Cambridge: Cambridge University Press.

NB Wittgenstein, L. (1961a). Notebooks 1914-1916. G. H. von Wright and G. E. M. Anscombe (Ed.), G. E. M. Anscombe (Tr.). Oxford: Blackwell.

OC Wittgenstein, L. (1969). On Certainty. G. H. von Wright and G. E. M. Anscombe (Ed.), G. E. M. Anscombe (Tr.). Oxford: Blackwell. 
Wittgenstein on the Grounds of Religious Faith

PG

Wittgenstein, L. (1974b). Philosophical Grammar. R. Rhees (Ed.), A. Kenny (Tr.).

Berkeley: University of California Press.

PI

Wittgenstein, L. (1953/2009). Philosophical Investigations. G. E. M. Anscombe, P.

M. S. Hacker and J. Schulte (Tr.). Revised fourth edition by P. M. S. Hacker and J.

Schulte. Oxford: Blackwell.

RFM Wittgenstein, L. (1983). Remarks on the Foundations of Mathematics. G. H. von

Wright, R. Rhees and G. E. M. Anscombe (Eds.), G. E. M. Anscombe (Tr.).

Cambridge Mass: MIT Press.

TLP Wittgenstein, L. (1961b). Tractatus Logico-Philosophicus. D. F. Pears and B. F. McGuinness (Tr.). London: Routledge.

\section{Other works}

Allison, H. (1986). Morality and freedom: Kant's reciprocity thesis. Philosophical Review 95, 393425.

Allison, H. (2001). Kant's Theory of Taste. Cambridge: Cambridge University Press.

Appelqvist, H. (2012). Apocalypse now: Wittgenstein's early remarks on immortality and the problem of life. History of Philosophy Quarterly 29 (2), 195-210. 
Wittgenstein on the Grounds of Religious Faith

Appelqvist, H. (2013). Why does Wittgenstein say that ethics and aesthetics are one and the same? In P. Sullivan and M. Potter (Eds.). Wittgenstein's Tractatus: History and Interpretation. Oxford: Oxford University Press, 40-58.

Appelqvist, H. (2016). On Wittgenstein's Kantian solution of the problem of philosophy. The British Journal for the History of Philosophy, 24 (4), 697-719.

Appelqvist, H. (2017). What kind of normativity is the normativity of grammar? Metaphilosophy 48 $(1-2), 123-145$.

Bell, D. (1987). The art of judgment. Mind 96 (382), 221-244.

Cottingham, J. (2017). Wittgenstein and philosophy of religion. In H. Glock and J. Hyman (Eds.). A Companion to Wittgenstein. London: Blackwell, 639-650.

Glock, H. (1992). Cambridge, Jena, or Vienna? The Roots of the Tractatus. Ratio 5 (1), 1-23.

Glock, H. (1997). Kant and Wittgenstein: Philosophy, necessity and representation. International Journal of Philosophical Studies, 5 (2), 285-305.

Glock, H. (1999). Wittgenstein and Schopenhauer: Language as representation and will. In C. Janaway (Ed.). The Cambridge Companion to Schopenhauer. Cambridge: Cambridge University Press, 422-458. 
Wittgenstein on the Grounds of Religious Faith

Hacker, P. (1986). Insight and Illusion. Oxford: Clarendon.

Hyman, J. (2001). The gospel according to Wittgenstein. In R. L. Arrington \& M. Addis (Eds.). Wittgenstein and Philosophy of Religion. London: Routledge, 1-11.

Kannisto, H. (1986). Thoughts and Their Subject. Helsinki: Acta Philosophica Fennica.

McGinn, M. (1999). Between metaphysics and nonsense: Elucidation in Wittgenstein's Tractatus. The Philosophical Quarterly 49 (197), 491-513.

Moore, A. (1987). Beauty in the transcendental idealism of Kant and Wittgenstein. The British Journal of Aesthetics 27 (2), 129-137.

Moore, A. (2013). Was the author of the Tractatus a transcendental idealist?. In P. Sullivan and M. Potter (Eds.). Wittgenstein's Tractatus: History and Interpretation. Oxford: Oxford University Press, 239-255.

Moyal-Sharrock, D. (2007). The good sense of nonsense: A reading of Wittgenstein's Tractatus as nonself-repudiating. Philosophy 82, 147-177.

Nielsen, K. (1967). Wittgensteinian fideism. Philosophy 42 (161), 191-209.

Nordmann, A. (2005). Wittgenstein's Tractatus: An Introduction. Cambridge: Cambridge University Press. 
Pears, D. (1987). The False Prison, Volume One. Oxford: Clarendon.

Sluga, H. (2011). Wittgenstein. Oxford: Blackwell.

Stenius, E. (1960). Wittgenstein's Tractatus: A Critical Exposition of its Main Lines of Thought.

Oxford: Blackwell.

Schroeder, S. (2007). The tightrope walker. Ratio (new series), XX (4), 442-463.

\footnotetext{
${ }^{1}$ It is impossible to give a comprehensive defense of the Kantian interpretation of Wittgenstein's early philosophy within the limits of this paper, and it is rather presupposed as the starting point of the argument to be developed on Wittgenstein's treatment of religious faith. For a defense of the Kantian interpretation, see, for example, Stenius 1960, Kannisto 1986, Glock 1992, 1997, 1999, Moore 1987, 2013, and Nordmann 2005. See also, Appelqvist 2012, 2013, and 2016.

${ }^{2}$ Translation slightly altered. In the original text Wittgenstein uses 'der Sinn der Welt', which I have translated as 'the sense of the world' instead of 'the meaning of the world' used in Anscombe's translation.

${ }^{3}$ To be sure, the connection between the (transcendental) will and the (empirical) nature, is a notoriously difficult question for Kant as well, and many scholars find his attempts to find a bridge between the domains of freedom and nature insufficient (see, for example, Allison, 1986). In this respect, Wittgenstein's denial of the very connection may be more consistent, if less satisfying as an answer to the question of the nature of ethics (see Moore, 1987: 132).

${ }^{4}$ See, for example, Hacker, 1986: ch. 4; Pears, 1987: ch. 7; Sluga, 2011: ch. 2. For an argument for a closer connection between Wittgenstein and Kant, see Glock 1999.

${ }^{5}$ Quite strikingly, these are the terms that Wittgenstein uses in relation to philosophy, calling the sentences of the Tractatus elucidations (TLP 6.54) and rejecting explanation in favor of mere description in the Philosophical investigations (PI $\S 109,124,126)$.

${ }^{6}$ See Allison, 2001: 144-159.

${ }^{7}$ The most explicit instance of the Kantian notion of purposiveness without purpose appears in Wittgenstein's Notebooks from 1916: 'And in this sense Dostoievsky is right when he says that the man who is happy is fulfilling the purpose [Zweck] of existence. Or again we could say that the man is fulfilling the purpose of existence who no longer needs to have any purpose except to live. That is to say, who is content' (NB: 73). Another term used by Wittgenstein for the experience of the world as a limited whole is the 'sense [Sinn] of the world/life', which according to him 'we can call God' (NB: 73; TLP 6.41). He also talks about the experience of the world or an object as 'significant [bedeutend]' (NB: 83). Yet, from the viewpoint of his early account of language, the world or an object cannot, strictly speaking, have any sense (Sinn) or significance or meaning (Bedeutung).

${ }^{8}$ The connection to Kant's account of space and time as constitutive of cognition is even more explicit in the Notes dictated to Moore in Norway from 1914. There, discussing internal relations that are necessary, logical relations between propositions and facts, Wittgenstein claims: 'From the fact that I see that one point is to the left of another, or that one colour is darker than another, it seems to follow that it is so; and if so, this can only be if there is an internal relation between the two; and we might express this by saying that the form of the latter is part of the form of the former. We might thus give sense to the assertion that logical laws are forms of thought and space and time are forms of intuition' (NB: 118). This final assertion is, of course, a clear paraphrase of Kant's position as it is outlined in the Transcendental Aesthetic and Transcendental Logic of The Critique of pure reason (CPR A 19-A 130).

${ }^{9}$ Here, the term 'object' is not used in the technical sense of the Tractatus, but refers to ordinary objects like the stove.

${ }^{10}$ Translation slightly altered. The original reads: 'An einen Gott glauben heisst, die Frage nach dem Sinn des Lebens verstehen. An einen Gott glauben heist sehen, dass es mit den Tatsachen der Welt noch nicht abgetan ist. An Gott glauben heist sehen, dass das Leben einen Sinn hat' (NB: 74).
} 


\footnotetext{
${ }^{11}$ I am not suggesting that Wittgenstein's view would be correctly characterized as non-cognitivist or fideist (see, for example Nielsen, 1967; for a criticism of the non-cognitivist view, see Cottingham, 2017). In fact, the very debate between cognitivism and non-cognitivism seems to hinge on the assumption that unless religious statements (or aesthetic judgments) do not have cognitive content, they are nothing but subjective responses. This is the very assumption that is called into question by Kant's Third critique. Moreover, as argued here, Wittgenstein follows Kant in this respect (See Appelqvist, 2017).

${ }^{12}$ It is another issue, outside the scope of this paper, whether religious faith must necessarily be understood in terms of affirming a certain religious doctrine. It is not just that many religious thinkers struggle with doubt, but that doubt itself seems to be an essential part, not just a minor wrinkle, of their religious lives. Besides, to put a lot of weight on a personal confession of faith is more typical in the reformed churches than it is in those old churches that emphasize the role of tradition as the seat of the truth of Christianity. Similarly, certain forms of Judaism treat participation in a Talmudic interpretative tradition, rather than a personal confessional commitment, as the core of religiosity.

${ }^{13}$ While it may seem strange to talk about satisfaction in the case of the grammatical rules of language, Wittgenstein himself illustrates the understanding of a sentence by comparing it with the understanding of a musical tune. The point is that in both cases my understanding may take the form, not of an ability to discursively explain the content of the sentence or the tune, but of an experience of the sentence or tune saying something that cannot be expressed by providing a paraphrase but only by further descriptions and comparisons (PI §§ 527, 531; see Bell, 1987 and Appelqvist, 2017).

${ }^{14}$ In Wittgenstein's later work, there are practically no references to ethics. Yet, consistently with his early equation between ethics and aesthetics, he states that what he says of the 'beautiful' is meant to apply 'in a slightly different way' to 'good' as well (TLP 6.421; M 9:18; LC I: 1).

${ }^{15}$ Earlier versions of this article were presented at the Helsinki Analytic Theology Workshop (Helsinki, January 15-16 2016), the Conference Wittgenstein and Religion (Heidelberg, November 11-13 2016), and the Seminar Literature in Philosophy of Religion (Helsinki, June 12 2017). I am grateful for feedback from the participants of these events, especially Danièle Moyal-Sharrock and John Cottingham, as well as Olli Koistinen and an anonymous referee of this journal. My thanks are also due to the Centre of Excellence Reason and Religious Recognition, funded by the Academy of Finland, as well as Turku Institute for Advanced Studies for providing support for my work.
} 